\title{
Can Genetics Help Us Understand Indian Social History?
}

\author{
Romila Thapar \\ Centre for Historical Studies, Jawaharlal Nehru University, New Delhi 110067, India \\ Correspondence: romila.thapar@gmail.com
}

\begin{abstract}
Attempts have been made recently to determine the identity of the so-called "Aryans" as components of the Indian population by using DNA analysis. This is largely to ascertain whether they were indigenous to India or were foreign arrivals. Similar attempts have been made to trace the origins of caste groups on the basis of varna identities and record their distribution. The results so far have been contradictory and, therefore, not of much help to social historians. There are problems in the defining of categories and the techniques of analysis. Aryan is a linguistic and cultural category and not a biological one. Caste groups have no well-defined and invariable boundaries despite marriage codes. Various other categories have been assimilated into particular castes as part of the evolution of social history on the subcontinent. A few examples of these are discussed. The problems with using DNA analysis are also touched on.
\end{abstract}

$T^{\text {hes }}$ he substantive part of the text deals with how contemporary historians have examined the evidence on race and caste in Indian history. They have discarded the first and have found the earlier definition of the second to be based on theory without adequate attention to caste as it actually functioned. Caste identity, particularly among the higher castes, and always assumed to be controlled by strict rules of marriage codes, has, in fact, been open to the assimilation of diverse groups for historical reasons. None of these identities were free of biological admixture.

Viewing the human populations of India since early history, it is assumed that genetic analyses can provide some evidence of their origins and of their social history. But the categories used in these analyses have emerged out of historical conditioning and, consequently, tend to bring the argument back to the historical. Current classifications of Indians by caste are almost entirely socially determined, barring the single exception of the biological difference of gender. The commonly used categories are race, caste, language, region, and some isolated habitats. Of these, race has been a dominant category in colonial scholarship during the last two centuries and caste goes back to much earlier times. Language was part of a larger differentiation. Region and habitat are of recent vintage.

Race as a category is unknown to traditional Indian classifications. It was imported from Britain and was used mainly by Europeans writing on Indian society, although subsequently it came to be used by Indians as well. What we call

Editor: Aravinda Chakravarti

Additional Perspectives on Human Variation available at www.cshperspectives.org

Copyright (C) 2014 Cold Spring Harbor Laboratory Press; all rights reserved; doi: 10.1101/cshperspect.a008599

Cite this article as Cold Spring Harb Perspect Biol 2014;6:a008599 
caste is referred to in Sanskrit sources by two concepts-varna and jati. They both assume identity through being born into a group and following a particular occupation. The first literally means color and was used rather metaphorically as such when referring to the four major caste groups-Brahmana, Kshatriya, Vaishya, and Shudra, sometimes listed as white, red, yellow, and black. Sociologists sometimes render the concept of varna as ritual or status ranking or alternately as the broader divisions of society. In the latter case, the meaning can be traced to "cover." The word jati comes from the root $j a$, meaning to be born. This refers directly to identity based on birth and also extends to occupation, but it is a narrower category than varna and there are hundreds of jatis observing various rules of endogamy and exogamy.

The Brahmanical normative texts, such as the Dharmashastras that incorporate the social codes, projected a society that closely observed the rules and allowed for little flexibility. This may be one reason why it was thought that caste society would lend itself to genetic analyses. However, the work of social historians has shown that this was not a description of how society actually functioned because a range of other texts provide evidence that the codes may have been formally observed but in fact were being broken. In effect, the caste would conform to its rank in the hierarchy of castes but the group that constituted the caste could change.

The beginnings of Indian history have been beset with contradictory theories about the origins of the peoples that created the fundamental cultures of India. These contradictions focus on the question of the origin of "the Aryans" and subsequently of "the Dravidians" (Dolgin 2009). Were the Aryans a people from Central Asia with cultural similarities to those of west Eurasia who migrated and settled in northwest India from where they spread across the subcontinent? Or were the Aryans indigenous to India, and according to some, spread their culture from out of India westward? Attempts have been made to use genetic analyses to determine the identity of various population groups and attempt an answer to these questions. The prob- lem remains, however, because no such groups have survived as a distinct entity from that period. Furthermore, the categories have been and constantly are redefined by historians and social scientists, and the redefinitions no longer allow an unimpaired existence across the centuries.

Historical evidence about the populations of that period-the second millennium $\mathrm{BC}$ is dependent on archaeology and history. Attempts have been made to corelate archaeological cultures in Central Asia with textual references from the Avesta composed in Old Iranian, and the Rigveda composed in Indo-Aryan. The closest is the Bactro-Margiana Archaeological Complex (BMAC), sometimes called the Oxus Civilization, dating to 2300-1900 BC, but even this is problematic (Staal 2008). Skeletal material from archaeological sites cannot be identified as "Aryan" because this is not a biological concept.

The western Orientalist reconstruction of Indian history begins with the Aryans as founders of Indian civilization. This, of course, is not the narrative in the early Indian Puranic "histories," which make no mention of any Aryans in this role. The invention of Aryan foundations, therefore, is a 19th century way of reading the beginnings of Indian history. The Vedic texts earlier were revered as texts of religious belief and practice and not as recording the beginnings of Indian history.

The word "arya" has two social and cultural connotations widely used in history but separated by 3000 years. The first is its meaning from Indian texts (Thapar 2008), but this meaning undergoes change through the centuries. Initially, it is a rather vague word used to describe those thought to be socially and culturally acceptable and worthy of respect, who used IndoAryan/Vedic Sanskrit as their language, and were relatively well-to-do. In the Rigveda, the Aryan is differentiated from the dasa, a word used to collectively describe the other component of the population. The dasa is associated with alien culture and speech, unfamiliar rituals, and with evil and darkness. Some, however, were rich in cattle wealth and subjected to raids by the aryas. Presumably it was these rich dasas who, apart from the aryas, occasionally were the 
patrons of Brahmin rituals. Gradually, the use of the word was extended to mean a person to be respected and was therefore used for Buddhist monks and for royalty. By the turn of the Christian era, it came to be used for the dvija/twiceborn upper castes, whereas the lower castes are described as non-aryas (Manu 1991).

This was read by 19th-century western Orientalists as referring to two races-the Aryan and the Dravidian-represented by the dasas. Both were language labels that came to be used interchangeably with race. The correct usage is Aryan-speaking and Dravidian-speaking peoples, but Aryan and Dravidian used as short cuts took on the meaning of race, ethnicity, and culture, with the imprint of race being the stronger. Similarities between Indo-Aryan and early European languages provided a basis for maintaining that there was an original Indo-European language spoken in Central Asia and that the speakers divided into two, with one branch going westward and the other finally arriving in India. The language and culture of the latter became the foundation of Hindu culture. The Aryans inevitably were the progenitors of the upper castes and the dasas, said to have been subordinated by the Aryans, of the lower castes (Trautmann 1997; Thapar 2008).

The construction of the terms Aryan and Dravidian grew from the study of Sanskrit and Old Tamil. Sanskrit was recognized as having cognates with Persian and Greek, and a theory of linguistic monogenesis was put forward by Sir William Jones at the end of the 18th century. A few decades later, Ellis and Caldwell argued for a parallel Dravidian group of languages. The Austro-Asiatic group, chiefly Munda, was regarded as dissimilar to both the others. The picture was one of multilingualism with each language being equated with a race. The equation was strengthened by the theories of what came to be called "race science" in Europe, which maintained that identification by race was based on scientific truth. Classification according to race was influenced by biological studies of the time and some degree of social Darwinism. Colonialism appropriated the notion that the colonizers were superior and the colonized, inferior.
The 19th century study of philology in Europe, which advanced rapidly after the inclusion of Sanskrit as a comparative language, made a particular impression on German Romanticism (Schwab 1984). Sanskrit was now spoken of as the ancestral language, a theory also advanced by those theosophists who had made India their home. This led to a search for an Indo-European homeland in Central Asia, later to be regarded as the source for proto-Indo-European speech. Many 19th century Europeans were searching for the "pure" Aryans and among them was the Comte de Gobineau.

This in part triggered the change to look for the homeland in Europe and the notion that the original Aryan may have been a blonde Nordic (Poliakov 1974). Measurements of the nasal and cephalic indices became crucial to proving racial purity. This turned into a major exercise in India where there was a project to confirm the classification of races by these measurements (Risley and Crooke 1915).

Max Mueller's study of the Vedas in the latter part of the 19th century and his reconstruction of the early Indian past put the stamp of authority on the theory of an Aryan race. Although well aware of not confusing race and language, he nevertheless proceeded to do just that, as did other scholars of the time. He argued that the word varna used for caste in the Vedic texts meaning color referred to the fairskinned Aryans and the dark-skinned dasas. Caste was much emphasized as the distinction between the upper caste Aryans and the lower caste Dravidians. One of the epithets used for dasas was a-nas, which he read as without a nose, and this was at a time when the measuring of nasal indices was regarded as firm evidence, although the alternative reading is an-as, without a mouth (i.e., not speaking a comprehensible language). Situations of conflicts between the two are mentioned and this was taken as proof that the Aryans invaded northwestern India and established themselves as conquerors in the mid-second millennium BC. This idea has now been discarded and the preference is for a graduated migration and much mixing with existing inhabitants-except among those few who continue to insist that the Aryans were in- 
digenous. Differences in language and rituals were obvious. The structure of Dravidian languages was not the same as that of Indo-Aryan and therefore the racial distinction was also underlined (Ramaswamy 1997; Trautmann 2006).

The Indian reaction to these theories at the end of the 19th century was an acceptance of their main ideas, which suited the identities sought by the emerging middle class. But these ideas were reformulated and eventually came to be used politically. The category of race was gradually replaced by caste. Because there was no word for race in Sanskrit, the term jati, which together with varna was used for caste, came to be used for race. The preference for jati was because its root came from ja, birth. This was partly responsible for the change.

Caste as a category of exclusion or as a part of social stratification has been a way of ordering societal characteristics of the Indian subcontinent for the past 2000 years. The stratification is based on dividing society into privileged and nonprivileged groups, the first constituted by the upper castes and the second by the lower castes. The normative condition was that social mobility was not to be allowed into the former, whereas control over the latter was not in effect possible. Three broad groups were outside the caste structure and often referred to as "mleccha": the untouchables/Dalits regarded as ritually polluted and who were physically segregated and formed a separate social system of their own, the tribal societies of the forest habitats, and those that came from other lands and cultures. There was a belief that an immobile, frozen society could be created and could function without change through enforcing the code of caste functioning, especially rules of marriage and inheritance.

The two systems of caste organization were juxtaposed. One was varna, where society was divided into four hierarchical components or castes. The normative texts, such as the Dharmashastra of Manu, were the social codes that in theory determined identity and functions. The relationship of one to the other is crucial to the system and conformation at least in theory, necessary. The other associated system was jati, in which there was again a hierarchical division.
Here the rules of birth and marriage were suggestive of the functioning of clan societies but with an emphasis on occupation, and written codes were largely absent. There was some attempt to find equivalences with the varna categories but this was problematic as jati hierarchies prevailed largely in the lower two varnas and as such they were more flexible. Neither system was as rigid as was hoped for in the normative texts. The mixing of castes was regarded as social degradation, yet many castes, high and low, resulted from such mixing. Among the more influential of these was the Kayastha caste of scribes and administrators. The exclusivity of caste was maintained but entry into an upper caste status could not be barred to other castes as is shown by the contradictions in the texts. Some royal families were of obscure origin but the genealogies made for them linked them to high castes, a case in point being the 18th century Maratha ruler, Shivaji. However, both the Orientalists-brought up on a diet of normative texts - and the Indian middle class, drawing inspiration from the former, believed in the purity of descent of each varna.

Indian interpretations of the theory of the Aryan race went from one extreme to another and shifted the identity of Aryan. Jyotiba Phule in Maharashtra turned the theory upside down, as it were (Deshpande 2002). He interpreted it as indicating that the original inhabitants were the lower castes who were made servile by an invasion of Brahmin/Aryan aliens. The latter took away the land of the former through guile. He drew on various myths as support for his ideas. The cultures that existed before the coming of the Aryans were therefore the creation of the lower castes. This argument has been useful to the identity of lower castes, particularly after the discovery of the Indus Civilization in the early 20th century, with which civilization they claim close links. Phule's reading shifted the focus from race onto caste with caste as the differentiating feature.

Upper caste authors ignored Phule. Thus, B.G. Tilak, for example, argued that the Aryans trekked from the Arctic where they originated and one branch came to India. Later, when there was an insistence that the Aryans were indige- 
nous to India, Tilak's theory continued to be accepted, but the location of the North Pole had to be shifted to within British Indian territory (Das 1920)!

The reverse of Phule's theory was propounded by Dayanand Sarasvati the founder of the Arya Samaj-the society of the Aryan race. Underlining the Brahmin perspective he stated that the Aryans were linguistically and racially pure and migrated from Tibet into India (Sarasvati 1935). He claimed that they established the purest and finest culture in India and that this should be revived. The upper castes were the Aryans from whose culture the untouchables/ Dalits were excluded. The latter could be incorporated once they had gone through a purification ritual. There were some common ideas between the Arya Samaj and the Theosophical Society, also active particularly in South India, during the later 19th century.

In the early 20th century there was another shift in the identity of the Aryan. H.V. Savarkar and M.S. Golwalkar changed the identification from caste to include religion. The Hindus were now defined not only as the primary citizens of India, but also as the Aryans in the Indian population. All others were aliens. The term Aryan was now given a religious connotation. India (i.e., the territory of British India), had to be the land of one's ancestors, pitribhumi, and the land where one's religion originated, punyabhumi. Therefore, only the Hindus were eligible. This was to be a foundational argument to the more extreme Hindu nationalism of the 20th century, often labeled as Hindutva. The concept of the Aryan was now getting enmeshed in a variety of interpretations and definitions, very different from its earlier meaning.

The discovery of the Indus civilization/Harappa culture in the 1920s with a script, still unread, changed the picture. The Aryans were no longer the bedrock of Indian history. The beginnings now went back to the Indus civilization. What was its identity? Is it different from the agropastoral society of the Vedic texts? The nuclei were the cities and these were unknown to the Vedas. Because the language has remained unread, claims have been made both by supporters of Indo-Aryan and proto-Dra- vidian viewpoints. One solution to the problem was to maintain that the Indus civilization was identical to the Vedic and represented its archaeological counterpart. This was first suggested by L.A. Wadell in 1925 when not much was known about the cities. The Hindutva ideologues in recent decades have been saying much the same but encountering opposition from many archaeologists and historians who find it unacceptable in the absence of evidence.

The latter had generally distanced themselves from variants of the theory. The initial argument had been that the Harappan cities declined owing to the invasion of the Aryans. This was questioned for lack of evidence and the decline traced to environmental factors. Extensive archaeological work in the Indus plain and adjoining areas revealed a large number of settlements of varied archaeological cultures, contemporary with the Harappan cities. Some of these continued into post-Harappan times. This has led to a reevaluation of the process by which the Indo-Aryan language spread in northern India. It seems more likely that there were small-scale migrations into the northwest and settlements within the vicinity of earlier settlements or even merging with these. The Rigveda, the earliest of the Vedic texts, is generally dated to between 1500 and 1000 BC. It shows linguistic elements and vocabulary from Dravidian and Munda languages, which may indicate bilingualism, which in turn would suggest a fair degree of mixing of the populations (Kuiper 1991; Witzel 1999). This would come about through intermarriage and the assimilation of each other's patterns of living.

Scholars have argued that even when cultures decline, there is always the possibility of some of their myths, rituals, and belief systems being continued through the oral tradition. This relates to the question of which of the two cultures was earlier. Archaeology generally provides reliable dates. Those for the Harappan cities point to a beginning in about $2650 \mathrm{BC}$ for the cities in the northwest and a slightly later start for those in western India. The decline comes about a thousand years later in approximately $1750 \mathrm{BC}$. Textual evidence is less easy to date. The date of the Rigveda is tied to evidence 
from elsewhere, such as cognate words and concepts in the Avesta from Iran, and the names of deities in the Mitanni-Hittite treaty of the 14th century BC. The treaty has archaic forms of Indo-Aryan and could therefore probably be a little older than the Rigveda. This would in fact date the Rigveda to later than 1500 BC. In any case, it cannot be contemporary with the Indus civilization. The sophisticated urban culture of the Indus cities is not reflected in the agropastoralism of the Rigveda. The question of chronology assumes centrality if the Harappans are to be described as Aryans as some are trying to do. This is more an argument of contemporary political ideology rather than that of an analysis of the textual and archaeological evidence.

Much of this particular argument results from a concern to determine the indigenous and the foreign groups in the population. But we must remember that there were no cartographic boundaries in those days. The boundaries of British India, which are the ones used in these discussions, were the much later creation of British colonialism. In the precolonial period, the effective boundaries were based on common languages, practices, customs, and political control, the last of which was blurred at the edges. These were often assumed and not necessarily well defined. In these circumstances, groups can only be defined as conforming, to a degree, to a particular culture rather than being clearly demarcated as either indigenous or foreign.

I have tried to trace the mutations of the term arya and the notion of Aryan as an exclusive category. Its application has changed over the centuries and new turns of meanings have been introduced even in the way it has been used by colonial and nationalist scholars. Clearly the connotation of race does not apply. To argue that they were an exclusive and self-perpetuating group is not meaningful. Historically, it makes greater sense to recognize that from the second millennium onward there has been a mixing of the descendants of the Harappans living in various parts of the north and the west with other populations of the time and subsequently with those that have migrated into the subcontinent at various times, starting with the Indo-Aryan speakers. The borderlands, in particular, had mixed populations. Some of these peoples then moved eastward into the Ganges valley with further mixing with the local populations there. The same procedure was followed in the movement southward into the peninsula. The degree of mixing cannot be ascertained, but linguistic traces of other languages in a given language can be used as a cautionary gauge.

There is now a turning to genetic data as a source for monitoring migrant and immigrant groups and arguing for a clear-cut descent of some of these. The intention within India is also to apply the results to ascertaining the identity of the Aryans. But as I have tried to show, Aryan is a social construct and therefore genetic information is unlikely to be useful unless the parameters defining the groups for analysis undergo some rethinking. Genetic data and analyses through the procedure of collecting and classifying samples may have to consider alternative criteria. Because the data involve social history, there is a very long span of time not only for new variation but also for assimilation from elsewhere.

Genetic profiles often assume that the claims of varna/caste categories as unchanging and exclusive are correct. But being socially created with no inherent natural rules, the identities of varna have undergone change. In the Vedic texts there is evidence of this. The most striking is the category called the dasi-putra Brahmanas. These are Brahmins identified as the sons of dasis. The word could mean either women of the dasa group or else a slave woman who would be of the lowest caste. In either case, the label contradicts the high status of the Brahmana claiming purity of descent. We are told that they were at first reviled by the regular Brahmins but when their superior ritual power was revealed they were eagerly assimilated into the orthodoxy. Their progeny would have been Brahmins but with a mixed ancestry. Among the better known in this category was the much-respected seer, Kakshivant (Brihad-devata 4.11-15; Aitareya Brahmana 8.23). A similar kind of recruitment to the Brahmana varna takes place in later centuries with the spread of Sanskritic courtly cul- 
ture to outlying areas. Priests from local jatis who picked up a smattering of Sanskrit were recruited to perform the rituals. Their composition of Sanskrit inscriptions shows their scant knowledge. But over a few generations the family would become proficient and claim to be of the high status Brahmin varna.

Another varna thought to be concerned with purity of descent is that of the Kshatriyas. As the warrior aristocracy of epic times, and the multitude of rulers that were scattered across the subcontinent from the late first millennium $\mathrm{AD}$, they were also viewed as a caste that preserved coherence over long periods. But, as it turns out, they are among the most open groups, perhaps because political power was in itself open. References to Kshatriyas occur in the later Vedic texts and in the Puranas (Wilson 1961). In both, there are long lists of succession and descent. Yet, even the most respected Kshatriya among them, Puru, the son of Yayati and ancestor to the protagonists of the Mahabharata, is said to have faulty speech, mridhra-vac (which would disqualify him as an arya), and descended from the demons, asura rakshasas (a serious disqualification of lineage).

In the late first millennium $\mathrm{AD}$, adventurers of obscure origin or feudatories who rose to independent status, would, on setting up independent kingdoms, claim to be Kshatriyas. Support came from Brahmins who prepared genealogies for them, which occasionally were fabricated, and performed the necessary rituals for their legitimation as Kshatriyas, in return for a fee, which was often a grant of land. Such grants became the nucleus of those Brahmin families who a few generations down claimed to be independent rulers of the lands granted, and these families constituted a new category of brahmakshatra, a mix of both (Fleet 1970). Mention is made in the Puranas of kings creating a caste of new Kshatriyas, sometimes from among those regarded as outside the pale of caste society. Dynasties of the period from ca. $500 \mathrm{BC}$ to AD 400 are said to be of either the Shudra or Brahmin caste. Foreign rulers, such as the Indo-Greeks, are described as vratya or degenerate Kshatriya. The category of Kshatriya was open to various castes that might wish to claim it, as happened from the latter part of the first millennium AD. Those claiming this status merely had to show their power in the open arena of politics.

The Shudra caste, as the lowest of the four, was also known to take on a variety of professions, from artisans to kingship. Those that ran the administration in many kingdoms were Kayasthas who are said to be of mixed castes, sometimes linked to one Shudra parent. Literacy was at a premium among these groups. Kayasthas in some instances are known to be authors of Sanskrit texts and as brilliant as their Brahmin counterparts.

It would seem therefore that to take varna as a consistent and controlled genetic group can be contrary to historical data. Nor can the caste codes as outlined in normative texts - the Dharmashastras - be taken literally. These were the idealized norms but obviously they were not widely observed, although the varna labels continued to be used. In fact, the jati structure of society is more reflective of social reality. But this network is perhaps too complex to be correctly followed for genetic analyses.

Categories of population groups are sometimes used as units of social analysis. But populations do not remain in one place for all time, and some among them frequently migrate. This is more characteristic of pastoralists in search of pastures and water supply than of sedentary agriculturists. But the latter are also dependent on fertile soil and water and therefore are known to have moved to many parts of the subcontinent in search of better conditions. The desiccation of the Indus plain led to migrations into the Ganges plain and from there in time to western and eastern India. In both of these areas there were prior populations of agriculturalists with whom the newcomers would have intermarried and have adopted some of their cultural traits. Encroachments into forested areas, increased from the late first millennium $\mathrm{AD}$, would also have involved interaction with the forest dwellers. The frequency of Apsarases, celestial maidens, entering the genealogies, is suggestive of marriage with women outside the caste. Activities linked to trade, by their very nature require travel and habitats in areas beyond the usual, with some degree of intermarriage. 
R. Thapar

All this creates a mixing of populations. The border areas of the subcontinent have been home to a variety of peoples. The northwestern borders received large groups of migrants from Central Asia, Iran, and Afghanistan. The northeast became home to groups coming in from Tibet, China, and Burma. The ritual specialists and the more learned members of the Brahmin varna were particularly mobile from the midfirst millennium AD. So too were the low status jatis of architects and sculptors. Architectural styles in the royal temples of the Himalayan kingdoms reflect the hand of artisans from distant parts of the plains. This met the demand for specialists of various kinds in the new kingdoms. Brahmins from Gauda (eastern India), Kanauj (central Ganges plain), and Kashmir were employed in courts distant from their homes. Some among these established new gotras and pravaras, subdivisions of the caste, the names of which suggest recruitment from local jatis.

Another category suggested for identifying groups is language. If this is used, then precision can only be assumed for current language speakers. Languages also migrate and travel and are used by speakers other than the original. Those associated with ritual and with social and political status, such as Sanskrit, are often the most sought after. The spread of Sanskrit to South India, which was a Tamil-speaking area, indicates elite groups seeking status through adopting this language, quite apart from its use in ritual. This also raises the question of how a group is to be defined through language because language also reflects social hierarchy. For example, how do we define speakers of English in India? Studies of language can, however, provide some clues. The migration of a language or its intersection with other languages can be traced to an approximate extent through comparative studies of syntax, morphology, and phoneticsmethods used in linguistics, but the methods have to be used with careful controls.

Social isolation and containment is not associated with castes, but with those that were excluded. It might be more useful to consider the DNA pattern among Scheduled Castes who have been regarded as untouchables throughout history and whose mixing with other groups was therefore limited. These groups, now referred to as Dalits, were isolated because they were thought by Brahmins to be polluting. They had their own social code distinct from the rest. Other isolated groups were the Scheduled Tribes whose habitat in forests encouraged their isolation. The best case of this would be the Jaravas of the Andamans. Others such as Angami Nagas and Muria Gonds may have ceased to be isolated some time ago. Comparative studies of such groups both among themselves and in relation to caste groups might be useful. The lower end of the social spectrum is likely to be more meaningful in studies of DNA from a historical perspective.

For the historian, and specifically the historian of ancient India, there are problems with using the results of what is termed ancient DNA. Samples collected from archaeological sites can be suspect for a variety of reasons. They can be contaminated through lying for a few thousand years in the soil, as in the case of burials, or in porous containers such as urns or wooden coffins. There can be decomposition and the growth of bacteria that would affect the result. Also, DNA gets chemically modified over time. It would seem that ancient DNA might require new techniques in collecting samples and analyzing them. Techniques are, however, improving and more reliable forms of assessing the evidence may well emerge.

Of the genetic studies performed so far, the results have been contradictory and historians at least find it difficult to use them with any certitude. The debate now involves not only ascertaining whether some groups were indigenous and others migrants but also the degree to which there were mixed communities. The question of whether "the Aryans" were indigenous to India or which of the castes should be regarded as inheritors of the land, are questions that touch on current political ideologies. There is a tendency to pick up only those results that suit a particular theory. It could be argued that even if answers are found to such questions, these would not necessarily clarify the picture of what happened in the ancient period of Indian history. The questions generally posed to 
genetic data have largely been based on confirming conventional views of the flow of social history. The contradictions that might emerge could be used to search for a different kind of analysis.

Mine is not an attempt to resist genetic analysis of populations in India. I would, however, maintain that where identities based on exclusions or differentiations are used, it is important to recognize that these are not naturally given but socially constructed. The social constructions also have to be taken into account, and if need be, the units of analysis have to be readjusted. One must remember that there was a time when science was believed to have certitude and that "race science" drew on this. Science has certitude within the parameters of known knowledge, but when the parameters change the certitude also changes and has to be adjusted to the new parameters.

Given the evidence, the defining of social groups for DNA analysis should perhaps be reconsidered instead of being restricted to race, caste, and language. So too, the techniques of examining the data from the past could perhaps be refined further.

\section{REFERENCES}

Das AC. 1920. Rigvedic India. Cosmo Publications, Delhi, India (reprinted in 1987).

Deshpande GP, ed. 2002. Selected works of Jyotirao Phule, pp. 23-100. Leftward, Delhi, India.
Dolgin E. 2009. The history of two distinct lineages led to most modern-day Indians. Nature doi: 10.1038/news. 2009.935.

Fleet JF, ed. 1970. Khoh copper-plate inscription of Maharaja Hastin. In Corpus inscriptionum indicarum (1888), Vol. III. Indological Book House, Varanasi, India.

Kuiper PBJ. 1991. Aryans in the Rigveda. Leiden studies in Indo-European, I. Rodopi, Amsterdam, The Netherlands.

Manu. 1991. Dharmashastra, pp. 10, 45, 57, 66-73. Penguin, Delhi, India (translated by W. Doniger and B. Smith).

Poliakov L. 1974. The Aryan myth: A history of racist and nationalist ideas in Europe. Basic Books, New York.

Ramaswamy S. 1997. Passion of tongues. University of California Press, Berkeley, CA.

Risley HH, Crooke E. 1915. The people of India. W. Thacker, London.

Sarasvati D. 1935. Satyartha prakash (Light of truth). Sarvadeshin Arya Pratinidhi Sabha, New Delhi, India.

Schwab R. 1984. The oriental renaissance: Europe's discovery of India and the East (1680-1880). Columbia University Press, New York.

Staal F. 2008. Discovering the Vedas. Penguin, Delhi, India.

Thapar R. 2008. The Rigveda: Encapsulating social change. In The Aryan: Recasting constructs. Three Essays Collective, Delhi, India.

Trautmann TR. 1997. Aryan and British India. Oxford University Press, New Delhi, India.

Trautmann TR. 2006. Languages and nations: The Dravidian roof in colonial Madras. University of California Press, Berkeley, CA.

Wadell LA. 1925. The Indo-Sumerian seals deciphered. Octavo, London.

Wilson HH, ed. 1961. The Vishnu Purana: A system of Hindu mythology and tradition, Book IV. Punthi Pustak, Calcutta, India.

Witzel M. 1999. Substrate languages in old Indo-Aryan (Rigvedic, middle and later Vedic). Electron J Vedic Stud 5: $1-97$. 


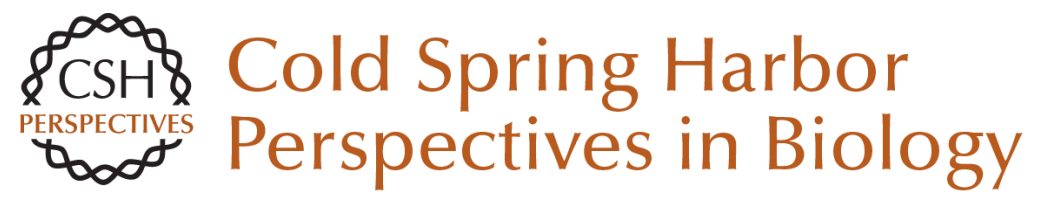

\section{Can Genetics Help Us Understand Indian Social History?}

Romila Thapar

Cold Spring Harb Perspect Biol 2014; doi: 10.1101/cshperspect.a008599 originally published online June 26, 2014

\section{Subject Collection Human Variation}

Perspectives on Human Variation through the Lens of Diversity and Race Aravinda Chakravarti

A Genomic View of the Peopling and Population Structure of India

Partha P. Majumder and Analabha Basu

Demographic Events and Evolutionary Forces

Shaping European Genetic Diversity

Krishna R. Veeramah and John Novembre

Social Diversity in Humans: Implications and Hidden Consequences for Biological Research Troy Duster
How Genes Have Illuminated the History of Early Americans and Latino Americans Andrés Ruiz-Linares

Can Genetics Help Us Understand Indian Social History? Romila Thapar

Genetic Variation and Adaptation in Africa: Implications for Human Evolution and Disease Felicia Gomez, Jibril Hirbo and Sarah A. Tishkoff

What Type of Person Are You? Old-Fashioned Thinking Even in Modern Science Kenneth M. Weiss and Brian W. Lambert

For additional articles in this collection, see http://cshperspectives.cshlp.org/cgi/collection/

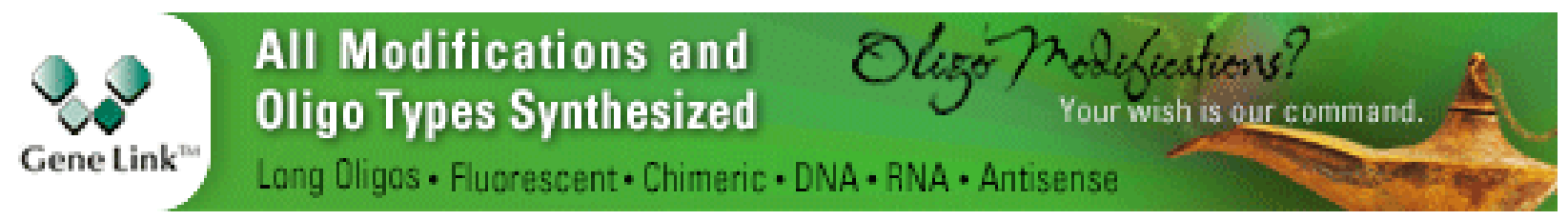

